\title{
Asessment of evaluation of transference support and training impact on the work of nurses
}

\author{
Lucelia Ferreira Lima Bastos $^{1}$ \\ Maria Helena Trench Ciampone ${ }^{2}$ \\ Vera Lúcia Mira ${ }^{3}$
}

\begin{abstract}
Objectives: to assess the impact of the Training Course on Prevention and Treatment of PU, in width and depth; to observe and analyze the variables of transference support of training, offered by the organization and to verify the existence of the relationship between transference support and training impact. Methods: this was a quantitative study, in which data were collected through the application of Likert-type instruments, conducted with 75 nurses participating in a training at a hospital organization in São Paulo city. Data were analyzed statistically. Results: there was a positive impact in width and depth, and the variables of transference support were strongly related to the impact, and situational factors of support were the main predictors of impact. Conclusion: the results pointed toward pathways to redirect the practice of instructional actions in the work environment of individuals in the study scenario and in similar situations that occur in organizations.
\end{abstract}

Descriptors: Transfer (Psychology); Learning; Training.

\footnotetext{
${ }^{1}$ MSc, RN, Hospital Israelita Albert Einstein, São Paulo, SP, Brazil.

${ }^{2} \mathrm{PhD}$, Full Professor, Escola de Enfermagem, Universidade de São Paulo, São Paulo, SP, Brazil.

${ }^{3} \mathrm{PhD}$, Associate Professor, Escola de Enfermagem, Universidade de São Paulo, São Paulo, SP, Brazil.
}

\section{Corresponding Author:}

Lucelia Ferreira Lima Bastos

Hospital Israelita Albert Einstein

Av. Albert Einstein, 627, GSMI, $3^{\circ}$ Andar, BI. E

Bairro: Morumbi

CEP: 05651-901, São Paulo, SP, Brasi

E-mail: lucelia.bastos@einstein.br
Copyright (c) 2013 Revista Latino-Americana de Enfermagem This is an Open Access article distributed under the terms of the Creative Commons Attribution Non-Commercial License (CC BY-NC).

This license lets others distribute, remix, tweak, and build upon your work non-commercially, and although their new works must also acknowledge you and be non-commercial, they don't have to license their derivative works on the same terms. 


\section{Background}

Currently, contextual changes resulting from scientific and technological developments are changing the world scenario and substantially affecting labor organizations. While obliged to act in line with these changes, or even anticipate them, organizations seek competitive advantages that allow them to be separated from their competitors by giving human resources a strategic position, while demanding from professionals the concrete demonstration of the effectiveness of their actions $^{(1)}$. The main challenge for Human Resources (HR) management is to prioritize human capital, equating it to any other essential resource for institutional development. Today, successful companies realize that they could improve performance by investing in their employees and making them outcome drivers, favoring positive returns for the whole organization and making the perception of work less focused and more systemic(2).

In the last two decades, research on training assessment has gained significant consistency, with findings highlighting variables that directly influenced training transference and impact for both the individual and the organization ${ }^{(3)}$.

It is important to distinguish concepts that are mistakenly used as synonyms. Training is intended to improve the performance of the trainee in a function that he/she performs. Human development is a concept that covers the full range of learning opportunities and experiences offered by a company, providing personal growth for the employee; and Education refers to the context of the opportunities offered by the organization for the development of individual potential through the learning of new skills, allowing the trainee to assume new job positions within or outside the organization ${ }^{(1,4)}$.

Learning is defined as a psychological process that refers to changes that occur in the behavior of the individual, after articulating their competencies, which is the set of knowledge, skills and attitudes, which are not the result, exclusively, of maturation, but of the interaction with the medium in which an individual is inserted, acquiring the ability to use knowledge in practice $^{(4)}$.

Researchers committed to ensuring the improvement of performance in the workplace have invested in the analysis of the acquisition, retention and transference of knowledge, skills and attitudes, through the actions of Training, Development and Education (TD\&E), with formation and professional qualification being the cited activities that are considered formal mechanisms of learning induction in organizations ${ }^{(3)}$.

Researchers emphasized that the main objective of this process was to analyze the behavior of the variables and understand how they affect work performance, providing data that support process improvement ${ }^{(1,3-4)}$

In institutions providing health services, the nursing staff composes the largest number of workers in health care, with this contingent estimated to reach $60 \%$. As a result, the success and effectiveness of education and training of these professionals are directly related to positive results obtained with best care practices.

The speed with which knowledge and technology innovate in healthcare is not accompanied by the formation of professionals, who require constant updating and are inserted into different models of services $^{(5)}$.

The reorganization of health services has increasingly become a priority, focusing on the development of people and culminating in the strengthening of labor operations. Therefore, policies for continuing education should be a priority in health worker training, requiring the application of specific managerial tools in the area of $H R$, which include assessment of the processes of recruiting, selection, training and development consistent with a new approach ${ }^{(5)}$.

In the health area, distinct actions for continuing education and permanent education in health have been developed, with the first aimed at the reorganization of services, and the latter at the transformation of the labor process, focusing on quality improvement, equity in care and access to health services ${ }^{(6)}$.

Continuing education in Brazil was established by the ordinance GM/MS n.198 of February 13th, 2004, subsequently amended by ordinance GM/MS n.1996, of August 20th, 2007, presenting new strategies and guidelines for the implementation of the National Policy for Continuing Education in Health (NPCEH). The NPCEH has as its objective the transformation of pedagogical and health care practices, contributing to the process of individual and collective development of health professionals(7).

Guidelines for work in health education, described in the Brazilian health pact, established that one should consider permanent education to be an essential part of training policies and staff development practices, 
adopting different and innovative teaching and learning strategies ${ }^{(7-8)}$.

Health institutions have been concerned with adopting the term permanent education, without revisiting their educational practices that are focused on traditional pedagogy and that present a scope that is not aligned to the proposals of the NPCEH. The need goes beyond changing a name; the need is to the reconstruct its meaning(9). A study published in 2011 confirmed this statement, by identifying contradictions between the permanent health education proposals and the experience of the facilitators, such as difficulty of democratizing the workspaces and of advancing the educational practices of pre-determined courses; and the desire for controlling the process and occupation of job positions ${ }^{(10)}$. When speaking of training workers, it is as if one were implying that these can be managed, in the same way, that other resources such as material, financial and infrastructure are managed; that is, as if it were possible to prescribe them beforehand: defining the expected skills, behavior and profile for an improved performance(5).

In this sense, the management style needs to change, moving from a central authoritarian paradigm, which emphasizes training for standardization of behaviors, to an education that favors the other to be thoughtful and creative, capable of co-responsibility for the execution of his/her activities ${ }^{(10)}$.

A paradigm such as that corresponds to the assumptions of meaningful learning and also of continuing health education; it is understood, however, that the educational activities in nursing are also marked by prescriptive instructional activities. It is possible to observe confirmations of this in the literature, where the forms of education undertaken, as well as the use of the word training, are cited not only as a term, but also because of its representation of professional preparation for ad hoc tasks(11). As an example, the literature shows a predominance of educational activities that are distinct from the concept of comprehensiveness and teamwork, emphasizing that such action reaffirms a clinical model of individual care, with fragmentation of actions, that are rarely evaluated(12).

In the literature, researchers found several training assessment models, and part of that inspiration is based on proposals by Donald $L$. Kirkpatrick, who built an evaluation model composed by four levels: reaction, learning, behavior change, and outcomes ${ }^{(1,4)}$.
The evaluation method developed by Borges and Andrade proposed a new model that was broader than previous ones, which aimed to capture information to evaluate an already in-progress program, to verify the outcomes achieved by the training, becoming a national reference $^{(13-14)}$.

Based on this model, another proposal was developed and validated, known as the Integrated Model for Impact Assessment of Work Training (IMPACT), which investigated variables related to the organization, entitled Organizational Support; to the training, entitled Training Features, and to the trainees, entitled Customer Characteristics $^{(13)}$.

Thus, the proposed models for the evaluation of training can be briefly defined as a systematic process of information collection that will guide a review and then propose improvements to the existent instructional model. These have as objectives: to control the process, to provide feedback into the system, and to make decisions about training that are capable of changing the environment ${ }^{(1,4)}$.

Experts state that the impact of training can be measured in width and in depth. For the depth analysis, the specific and direct effects of training, associated to the content of the training program, are measured; while the impact of width, also called amplitude, measures the training effects in relation to the overall performance expected for the position by the organization, or that are not linked to skills learned during the instructional event $^{(13)}$.

The measure of impact on TD\&E allows an outcome evaluation to verify whether the instructional actions were able to modify the individual and organizational performance after the training program ${ }^{(14)}$. The impact can also be evaluated by the learning transfer and the influence of the instructional process in the trainee's performance, when he/she correctly applies the abilities that compose the set of acquired knowledge, skills and attitudes $(\mathrm{KSA})^{(9)}$.

Given these incipient results in this healthcare topic, we conducted an integrative review aiming to analyze the methodology for evaluation of health professionals' formal educational activities. The author analyzed 19 articles, published from January 2000 to July 2010. The findings in most of the studies focused only on the level of learning (73.6\% of the articles); only $15.0 \%$ of the research was intended to assess impact, and only one was referred for replication. We concluded that there was little progress for the thematic area of health care, evidenced in only two publications in the last decade ${ }^{(15)}$. 
In many healthcare organizations, the more viable techniques to enforce training assessment consist of evaluating the levels of reaction and learning, not necessarily getting essential information of other levels of the chain (individual and organizational), for a consistent and conclusive evaluation. In general, adequate tools or methodologies are still not available to analyze the relationship between variables or to know the value added by the training to the individual, to the workplace, and to the organization. Although the literature review indicated major advances related to training evaluation, the knowledge generated has been little used in the practice of health institutions.

The acquired knowledge in educational activities is not always practiced due to organizational and managerial problems $^{(6)}$. One also knows that the achievement of learning in practice - the impact - depends, among other things, on the working conditions - the support for transference - and we consider that, in addition to assessing the acquisition of post- training knowledge, it is essential to assess aspects of the environment where the target objective of the training occur. We emphasize that, given the instructional method aimed to improve technical abilities and the didactic strategy (traditional education), the action chosen is considered to be training.

Therefore, intending to address the following questions: "does training have an impact on the job?" and "does the environment provide the necessary conditions to apply what was learned in the workplace?" the aim of this study was to assess the impact of the Training on Prevention and Treatment of Pressure Sores, in width and in depth; to observe and analyze the variables that support the transference of the training offered by the organization; and to verify the relationships between support of transference and training impact.

\section{Method}

\section{This was a quantitative and descriptive study}

The institution in which the study was conducted was a social health organization named Hospital Municipal Dr. Moysés Deutsch (HMMD), with an exclusive care to the network of the Unified Health System (SUS). The Training on Prevention and Treatment of Pressure Sores of the HMMD required mandatory participation for all nurses who worked in areas presenting pressure ulcer risk, and the course was divided into four classes, and was conducted between July and August of 2011.
The study population had targeted 89 nurses active for more than 90 days in the institution, working in units with higher incidence of pressure ulcers: the Internal Medicine and Surgical Center (IMSC), Emergency Room (ER), Adult Intensive Care Unit (AICU) and the Home Care Program (HCP), across the three work shifts.

The ER unit was included in the study due to its relevant incidence of pressure ulcers related to the high average length of stay of users in this area, caused by the lack of availability of inpatient beds to meet demand.

The assessment tools for depth andwidth impact, and support for transference, were divided into sessions, the first containing personal and functional data, the second for the assessment of the depth impact, related to the training objectives and containing nine statements, associated with a Likert scale rating from 1 to 5 ( 1 for "never use" and for "always use"), and the third session for the assessment of the width impact, containing 13 items ranging 1 to 5, with 1 meaning "strongly disagree" and 5 meaning "totally agree". Finally, there is a self-assessment about the effects of the training on the trainee's performance, motivation, self-confidence, and their openness to changes in work processes.

The assessment tools for variables that support the transfer were subdivided into: Situational factors of support, which allow the participant to evaluate the managerial, social and organizational support that he/ she receives to apply the new skills learned during the training; Material support, which refer to the opinion of trainees as to the quality, quantity and availability of material resources, as well as the suitability of the physical environment of the workplace to the transfer of training; and, Consequences, which is associated with the use of new skills, and relates to the participant's opinion about the reactions of peers or supervisors in the attempt to apply the new skills learned at work. All tools used a Likert scale with scores ranging from 1 to 5 , with 1 meaning "never occurs", and 5 meaning "always occurs".

The tool to measure the depth of impact related to the training objectives was developed by the researcher, based on the original IMPACT instrument, developed and validated by Abbad in 1999. The same author developed the remaining versions of the instrument, maintaining the original version, adapted solely to the organization's profile.

To identify the number of domains in the modified version of the instrument, an exploratory factor 
analysis by maximum likelihood was conducted. It showed evidence of adaptation to a two-factor structure, which explained $47.3 \%$ of the total variance, with a factor 1 Cronbach's alpha value of 0.822 , and a factor 2 Cronbach's alpha value of 0.702 . The instruments that measured the width impact and the one that measured the support for transference showed satisfactory internal consistency, according to the calculated Cronbach's alpha coefficient. The lowest rate observed was 0.692, showing that the original structure of the instrument remained in this study population.

Data were collected from July to October 2011, after the approval of the Hospital Board of Ethics (Process 11/1551) and the achievement of informed consent under the direction of the institution in which the study was conducted.

The instruments were given to the trainees, who consented to participate in the research through the Terms of Free and Informed Consent Form, 30 days after the instructional action.

The presence of association between the scores on the sections of the support instrument to transfer and impact was investigated by calculating the Spearman's correlation coefficient between variables.

\section{Results}

The study population targeted 89 nurses: 22 were working in the Internal Medicine and Surgical Center (IMSC), 42 in the Emergency Room (ER), 20 in the Adult Intensive Care Unit (AICU) and 5 in the Home Care Program (HCP). Of these 89, only 75 met the eligibility criteria. A greater participation of nurses from the Intensive Care Unit was observed (100\%), followed by the IMSC $(90.1 \%)$, ER (76.2\%) and HCP (75.0\%).

Of the 75 (84\% of the target population) professionals included in the study, most were female $(81.3 \%)$, and $46.7 \%$ were qualified as specialists. Regarding the distribution of trainees per shift, we observed a uniform distribution, with a slight predominance of nurses working in the afternoon shift $(37 \%)$, while $32 \%$ were from the morning shift, and $31 \%$ from the night shift.

The mean age of participants was 29.4 years, with a standard deviation of 5.5 years. The minimum age observed was 22 years and the maximum age 41 years. The time of employment ranged from 4 to 42 months, with a mean time of 22.5 months and a standard deviation of 13.6 months.

According to Table 1, we observed the summary measures analyzed of 0 to 10 with a positive impact on the population studied:

Table 1 - Summary measures of the impact of the Training in Prevention and Treatment of Pressure Ulcers, Hospital Municipal Dr. Moysés Deutsch, São Paulo, SP, Brazil, 2011

\begin{tabular}{|c|c|c|c|c|c|}
\hline Impact & Mean & $\begin{array}{l}\text { Standard } \\
\text { Deviation }\end{array}$ & Minimum & Median & Maximum \\
\hline Depth impact (0 to 10$)$ & 7.91 & 1.36 & 3.89 & 8.06 & 10.00 \\
\hline Width impact (0 to 10$)$ & 8.17 & 1.07 & 5.58 & 8.46 & 10.00 \\
\hline Situational factors of support ( 0 to 10$)$ & 6.50 & 1.25 & 3.33 & 6.67 & 8.89 \\
\hline Material support (0 to 10$)$ & 7.78 & 1.62 & 2.50 & 7.50 & 10.00 \\
\hline Consequences associated with the use of new skills ( 0 to 10$)$ & 6.67 & 1.53 & 2.86 & 6.43 & 10.00 \\
\hline Impact (0 to 10$)$ & 7.48 & 0.99 & 5.06 & 7.38 & 9.65 \\
\hline
\end{tabular}

As seen in Table 2, the assessment of the relationship between support factors and impact showed that situational factors of support were strong predictors of impact, followed by the consequences associated with the use of new skills. Although the relationship between material support and impact was significant, in this study this factor showed a low predictive impact.

Professionals who had better supervision with regard to incorrect practice reported a greater impact of the training on their work (Spearman correlation coefficient $=0.283, \quad p=0.014) ; \quad$ whereas $40 \%$ of respondents stated that they were not corrected when they made mistakes regarding new skills.

The impact on the workplace was lower among those who claimed lack of time to acquire new skills (Spearman correlation coefficient $=-0.137, p=0.243$ ).

The better the conditions of the environment and structure, the greater the impact of training on the workplace (Spearman correlation coefficient $=0.425$, $\mathrm{p}<0.001)$. 
Table 2 - Variables of transference support and impact of the Training on Prevention and Treatment of Pressure Ulcers, Hospital Municipal Dr. Moysés Deutsch, São Paulo, SP, Brazil, 2011

\begin{tabular}{|c|c|c|c|}
\hline \multirow[b]{2}{*}{ Support } & \multicolumn{3}{|c|}{ Impact } \\
\hline & $\begin{array}{c}\text { Depth } \\
\text { impact }\end{array}$ & $\begin{array}{l}\text { Width } \\
\text { impact }\end{array}$ & $\begin{array}{c}\text { Impact } \\
\text { (0 to 10) }\end{array}$ \\
\hline \multicolumn{4}{|l|}{ Situational factors of support } \\
\hline Correlation coefficient & 0.590 & 0.593 & \\
\hline p-value & $<0.001$ & $<0.001$ & \\
\hline \multicolumn{4}{|c|}{ Consequences associated to the use of new skills } \\
\hline Correlation coefficient & 0.371 & 0.443 & \\
\hline p-value & 0.001 & $<0.001$ & \\
\hline \multicolumn{4}{|l|}{ Material support } \\
\hline Correlation coefficient & 0.319 & 0.389 & \\
\hline p-value & 0.005 & 0.001 & \\
\hline \multicolumn{4}{|l|}{ Transfer support (0 to 10$)$} \\
\hline Correlation coefficient & & & 0.649 \\
\hline$p$-value & & & $<0.001$ \\
\hline
\end{tabular}

\section{Discussion}

It is recognized that although the assessment processes developed in Brazil are not below those found internationally, we found in the literature the predominance of a systematic practice, particularly in the area of health care provision. This fact makes the analysis of training outcomes a challenging task, considering the area and theme of the chosen training, and the selected scenario which constituted the study.

Based on the research findings, the assessment enabled the discussion of the models used predominantly in the cognitive domain, based in overly expository teaching methodologies, with little or no interface with the post-training environment, and quantitative assessments.

Experts point out that if there is no support for transference, the acquisition of KSA by itself will be insufficient to generate changes in the work environment at both the team level and organizational level(13).

Variables that support transference are considered strong predictors of impact. Organizations need to conduct evaluations of these items before submitting teams to training that may not be effective when they return to their workplaces ${ }^{(3,13)}$.

We emphasize that $40 \%$ of participants reported that they were not warned or corrected when they made a mistake during the practice of new skills. We found an important gap in the role of the nurse supervisor, in the sense of monitoring, developing and strengthening this knowledge in nursing practice. These data coincide with the findings of other recent studies, where one observes a significant contingent of leaders adopting a bureaucratic and managerial-based practice, still distant of a model articulated and focused on care management, a practice that requires application of participative and inclusive strategies ${ }^{(16)}$.

The findings of this research regarding the support for transference revealed some fundamental conditions, necessary for the application of knowledge in the workplace. If support was not perceived, it could hamper and even prevent the effective performance and transference of training.

Studies of organizational psychology suggest that the variables that support transference are the most important predictors of the training impact, but warn that know-how and organizational support are necessary conditions, but are not sufficient for effective performance. To want to do is as necessary as knowledge in order for subjects to achieve a better result according to the set of expectations and standards ${ }^{(13)}$.

Studies indicate the need to investigate the relationship between impact and other levels of outcomes, exploring the post-training environment, i.e., understanding how this scenario affects the expected key results, which is the application of KSA within work situations, and whether training changed trainee

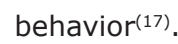

\section{Conclusion}

Positive impacts were observed in width and depth, and the variables that supported transference were strongly related to this, with the situational factors of support being the main predictors of transference. The findings suggested that perceptions of the trainees 
about received support directly influenced the impact of training in the workplace.

This study has shown the need for continuous research and refinement of the assessment process on the impact of formal instructional actions, considering the limits and potentials of the methods, techniques and tools, both in this study setting, as well as in other scenarios of health services. The findings pointed to an unquestionable need for implementation of adjustments that cover all stages, because a diagnosis is useless if it does not trigger an appropriate action and intervention in the process.

As for limitations of this study, we recognized the need to increase the sample size in order to ensure reliability and validity of the instruments.

\section{References}

1. Meneses PPM, Zerbini T. Levantamento de necessidades de treinamento: reflexões atuais. Análise. jul-dez 2009;20(2):50-64.

2. Campos KC, Barduchi AL, Marques DG, Ramos KP, Santos LA, Becker TJ, et al. Avaliação do sistema de treinamento e desenvolvimento em empresas paulistas de médio e grande porte. Psicol Reflex Crít. $2004 ; 17(3): 435-46$.

3. Tamayo N, Abbad GS. Autoconceito profissional e suporte à transferência e impacto do treinamento no trabalho. Rev Adm Contemp. [Internet]. 2006 [acesso 23 dez 2010];10(3):9-28. Disponível em: http://www. scielo.br/pdf/rac/v10n3/a02v10n3.pdf

4. Pantoja MJ, Borges-Andrade JE. Estratégias de aprendizagem no trabalho em diferentes ocupações. RAC Eletr. [Internet]. 2009 [acesso 13 abr 2011];3(1):4162. Disponível em: http://www.anpad.org.br/periódicos /arq_pdf/a_833.pdf

5. Ceccim RB. Educação permanente em saúde: desafio ambicioso e necessário. Interface. (Botucatu). 2005;9(16):161- 8.

6. Murofuse NT, Rizzotto MLF, Muzzolon ABF, Nicola AL. Diagnosis of the situation of health workers and the training process at a regional center for professional health education. Rev. Latino-Am. Enfermagem. [Internet]. 2009 Jun [acesso 3 jun 2013] ; 17(3): 314-20. Disponível em: http://www.scielo.br/scielo.php?script=sci_arttext\&pid =S0104-11692009000300006\&lng=pt. http://dx.doi.org/ 10.1590/S0104-11692009000300006.

7. Ministério da Saúde (BR). Portaria GM n. 1996, de 20 de agosto de 2007. Dispõem sobre as diretrizes para a implementação da Política Nacional de Educação
Permanente e dá outras providências [Internet]. Brasília (DF); 2009 [acesso 15 jul 2012]. Disponível em: http:// dtr2001.saude.gob.br/sas/PORTARIAS/Port2007/GM/ GM-1996.htm

8. Fortuna CM, Franceschini TRC, Mishima SM, Matumoto S, Pereira MJB. Movements of permanent health education triggered by the training of facilitators. Rev. Latino-Am. Enfermagem. mar-abr 2011; 19(2):411-20.

9. Mira VL. Avaliação de programas de treinamento e desenvolvimento da equipe de enfermagem de dois hospitais do município de São Paulo [tese livre-docência]. São Paulo: Escola de Enfermagem da Universidade de São Paulo; 2010.

10. Bueno AA, Bernardes A. percepção da equipe de enfermagem de um serviço de atendimento préhospitalar móvel sobre o gerenciamento de enfermagem. Texto Contexto Enferm. jan-mar 2010;19(1):45-53.

11. Silva MAS, Pimenta Cibele AMC, Cruz DALM. Treinamento e avaliação sistematizada da dor: impacto no controle da dor do pós-operatório de cirurgia cardíaca. Rev Esc Enferm USP. fev 2013;47(1):84-92.

12. Tronchin DMR, Mira VL, Peduzzi M, Ciampone MHT, Melleiro MM, Silva JAM, et al. Educação permanente de profissionaisdesaúdeeminstituiçõespúblicashospitalares. Rev. Esc Enferm USP. [Internet]. dez 2009 [acesso 2 jun 2013] ; 43(spe 2): 1210-5. Disponível em: http:// www.scielo.br/scielo.php?script=sci_arttext\&pid= S0080-62342009000600011\&lng=en.http://dx.doi.org/ 10.1590/S0080-62342009000600011

13. Abbad G. Um modelo integrado de avaliação do impacto de treinamento no trabalho - IMPACT [tese doutorado]. Brasília (DF): Universidade de Brasília; 1999.

14. Freitas IA, Borges-Andrade JE, Abbad GS, Pilati R. Medidas de impacto em TD\&E no trabalho e nas organizações. In: Borges-Andrade JE, Abbad GS, Mourão L. Treinamento, desenvolvimento e educação em organizações e trabalho: fundamentos para a gestão de pessoas. Porto Alegre: Artmed; 2006. p. 489-504.

15. Otrenti E. Avaliação de processos educativos formais para profissionais da área da saúde: revisão integrativa da literatura [dissertação]. São Paulo: Escola de Enfermagem da Universidade de São Paulo; 2011.

16. Carvalho JF, Chaves LD. Supervisão de enfermagem no contexto hospitalar: uma revisão integrativa. Rev Eletr Enferm. [Internet]. 2011 [acesso 9 ago 2012]; 13(3):546-53. Disponível em: http://www.fen.ufg.br/ revista/v13/n3/v13n3a21.htm 
17. Abbad G, Gama AL, Borges-Andrade JE. Treinamento: análise do relacionamento da avaliação nos níveis de reação, aprendizagem e impacto no trabalho. RAC. 2000;4(3):25-45. 